\title{
Effect of Different Physico-Chemical Parameters on Production of Amylase by Bacillus Species.
}

\author{
${ }^{1}$ Neeraj Kumar Lohani $*{ }^{2}$ P.D .Trivedi, ${ }^{3}$ Divakar Joshi, \\ ${ }^{1}$ Institute of Biomedical Education \& Research, Mangalayatan University, Aligarh-Uttar Pradesh, India*, \\ ${ }^{2}$ Central Drug Research Institute Lucknow-Uttar Pradesh,India, ${ }^{3}$ M. B. Govt. P. G. College Haldwani, Kumaun \\ University Nainital- Uttrakhand, India.
}

\begin{abstract}
The present study is concerned with the production of amylase by Bacillus species strain. In this study 12 bacterial strains were isolated and screened for their $\alpha$-amylase activity. These strains were maintained on nutrient agar medium. Fermentation for the production of amylase was carried out in the enzyme production medium (EPM). All the 12 strains were tested for amylase production. On the basis of maximum amylase activity strain no. 1 was selected for further studies. Different starch concentrations, $0.75,1.00,1.25 \%$, pH labels 6.5,7.0,7.5,8.0, aeration (RPM), 100,120,140, temperatures $25^{\circ} \mathrm{C}, 28^{\circ} \mathrm{C}, 37^{\circ} \mathrm{C}$, and $40^{\circ} \mathrm{C}$ and inoculums level $0.5 \%, 1.0 \%, 1.5 \%$ and $2.0 \%$ were studied.
\end{abstract}

Key Words: Amylase, Bacillus species.

\section{Introduction}

Amylase is an extracellular enzyme degrades $\alpha, 1-4$ glucosidic linkages of starch and related substrates in an endo-fashion producing oligosaccharides including maltose, glucose and alpha limit dextrin (Calik\&Ozdamar., 2001). Which have been derived from plants, animals and several microorganisms like bacteria (Vidyalakshmi P et al., 2009 Busch JE et al.,1997)and fungi.But the Bacillus species such as B. subtilis, B.licheniformisand B. sterothermophiliscan be used for thebetter production of amylase in shake flask (Mamo\&Gessesse., 1999).Amylase has great significant in biotechnology and are commercially important in various starch processing industries (Guzman et al., 1995). The enzymes from microbial sources generally meet industrialdemands.

The production of amylase is dependent on the strains, composition of media, methods of cultivation, cell growth, nutrient requirement, inoculum size, $\mathrm{pH}$, temperature, time of incubation. The effect of starch concentration on the relative activity of amylase from B. species was detected and starch concentration for optimum production was $0.5-2.0 \%$. The effect of temperature on the relative activity of amylase from B. species was detected and temperature was optimized between $30^{\circ} \mathrm{C}-40^{\circ} \mathrm{C}$, for maximum activity (Kim et al., 1995). The production of the amylase is effected by aeration rate (RPM) the aeration rate at the level of 100-140 was studied. The size of inoculum has marked effect on the growth of the bacteria and biosynthesis of amylase as reported by (Allan et al., 1996).the inoculum at the level of 1-2\% was studied for theproduction of amylase enzyme. The inoculum size was increased; the production of enzyme was decreased. The production and stability of the enzyme is very sensitive to $\mathrm{pH}$ observed that amylase obtained from B. species was stable at $\mathrm{pH}$ 6.5 -8.0 (Ivanova et al., 1993).

\subsection{Chemicals Used}

\section{Materials And Methods}

Table 1. Chemicals Used

\begin{tabular}{|c|c|c|}
\hline S.No. & Name Of The Chemicals \& Reagents & Manufacturer \\
\hline A. & Ammonium Sulphate & Sisco Research Laboratories Pvt. Ltd. (Mumbai). \\
\hline B. & Starch & Qualigens \\
\hline C. & Sucrose & $\begin{array}{c}\text { Sisco Research Laboratories Pvt. Ltd. } \\
\text { (Mumbai) 400099 India. }\end{array}$ \\
\hline D. & 3,5-Di Nitrosalicylic Acid(DNS) & $\begin{array}{c}\text { Sisco Research Laboratories Pvt. Ltd. } \\
\text { (Mumbai) 400099 India. }\end{array}$ \\
\hline E. & Sodium Hydroxide & Thomas Baker \\
\hline F. & Zinc Sulphate & LobaChemiPvt.Ltd. Mumbai-400 005 \\
\hline
\end{tabular}


Effect of different physico-chemical parameters on production of Amylase by Bacillus Species.

\begin{tabular}{|c|c|c|}
\hline G. & Urea & Qualigens Fine Chemicals. \\
\hline H. & Magnesium Sulphate & Qualigens Fine Chemicals \\
\hline I. & Peptone & Qualigens Fine Chemicals \\
\hline J. & D-Glucose & Qualigens Fine Chemicals \\
\hline K. & Ferrous Sulphate & Qualigens Fine Chemicals \\
\hline L. & Potassium Sodium Tartarte & Qualigens Fine Chemicals \\
\hline M. & Di-Potassium Hydrogen Ortho Phosphate & Qualigens Fine Chemicals \\
\hline N. & Calcium Chloride & Sds Lab Rasayan \\
\hline O. & Cobalt Chloride & LobaChemiPvt.Ltd. Mumbai \\
\hline
\end{tabular}

\subsection{Apparatus Uses}

Table 2. Apparatus Used

\begin{tabular}{|c|c|c|}
\hline S.No. & Name Of Equipment \& Instrument & Manufacturer \\
\hline A. & $\begin{array}{c}\text { All Glass Ware } \\
\text { ( Sterilize Glass Pipette, Sterilize Test Tubes, } \\
\text { Glass Rod, Conical Flask, Beaker) }\end{array}$ & Borosil. \\
\hline B. & $\begin{array}{l}\text { ALL PLASTIC WARE(Measuring } \\
\text { Cylinder, Appendoff Tubes) }\end{array}$ & Tarson. \\
\hline C. & Autoclave & $\begin{array}{l}\text { Mac, Macro Scientific Work } \\
\text { Lab.Equipments, 10/Ua(Delhi) }\end{array}$ \\
\hline D. & Digital Oven & Tanco An Iso 9001:2000 Co. \\
\hline E. & Incubator Shaker & $\begin{array}{l}\text { Lark, Innovative Fine Technolwledge 1037, 4o } \\
\text { Th Street, Chennai. } 600080 \text { India. }\end{array}$ \\
\hline F. & Laminar Air Flow & $\begin{array}{c}\text { Mac, Macro Scientific Work, (10a/Ua) J.N. } \\
\text { Delhi } 7\end{array}$ \\
\hline G. & Microwave Oven & Kenstar \\
\hline H. & $\begin{array}{l}\text { UV Double Beam Spectrophotometer } \\
\text { Model: Uv-2601 }\end{array}$ & $\begin{array}{l}\text { Beijing Rayleigh Analytical Instrument Corp. } \\
\text { Bldg. A5, No.9 Jiuxianiao East Road, } \\
\text { ChaoyangDistt. Beijing 10016, P.R. China }\end{array}$ \\
\hline I. & Spin Win & $\begin{array}{c}\text { Tarson Product Pvt. Ltd. Jasmin } \\
\text { Tower,(Kolkata,700017) }\end{array}$ \\
\hline J. & Vortex Shaker & $\begin{array}{c}\text { Mac, Macro Scientific Work, (10a/Ua) J.N. } \\
\text { Delhi } 7\end{array}$ \\
\hline
\end{tabular}

DNS reagent, sterilize medium, cotton, tissue paper, $70 \%$ ethanol are also used during experiment.

\subsection{Method}

\subsubsection{Isolation of Bacillus Culture}

This study was carried out at biotech department M.B. Govt. P.G. College Haldwani Nainital.Bacillus cultures were isolated from soil by serial dilution method.1gm soil sample from the college campus was suspended in $10 \mathrm{ml}$ sterilized distilled water the soil suspension was diluted to 10-7 and .1ml diluted suspension was speared on the nutrient agar plate containing starch and this volume spread by a triangular glass spatula evenly and incubated at $37^{\circ} \mathrm{c}$ for 24 hours. After 24 hour 12 bacillus colonies were picked up in nutrient agar slant which were morphologically identified by gram stain method and all were found gram positive bacilli. 


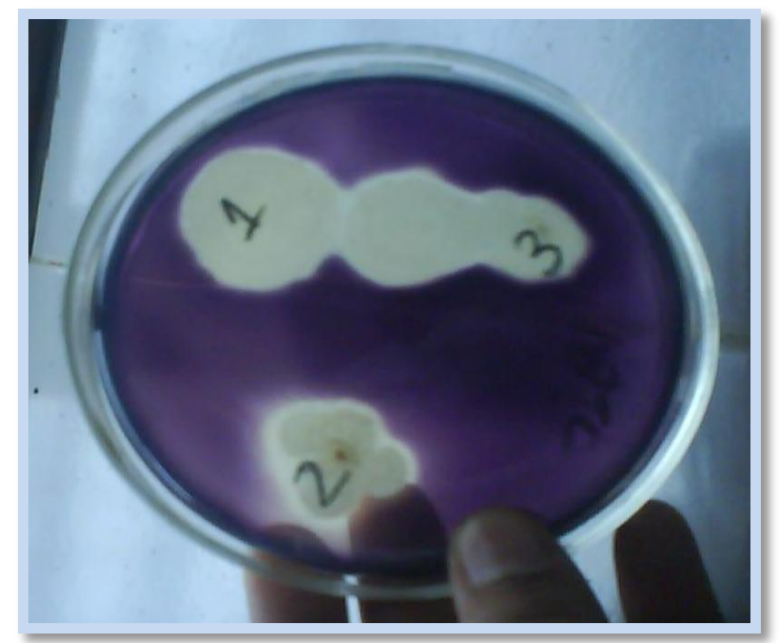

Figure 1.Bacillus Culture isolated from soil sample.

Table 3.Cmposition of Fermentation Medium

\begin{tabular}{|c|c|}
\hline Bacteriological peptone & $6.0 \mathrm{gm} / \mathrm{l}$. \\
\hline Mgso4.7H2O & $0.5 \mathrm{gm} / \mathrm{l}$. \\
\hline KCL & $0.5 \mathrm{gm} / \mathrm{l}$. \\
\hline Starch & $1.0 \mathrm{gm} / \mathrm{l}$. \\
\hline
\end{tabular}

The above ingredients were mixed and distributed in $100 \mathrm{ml}$ Eyrlen Meyer flask sterilized by autoclaving at $121^{\circ} \mathrm{c}$ for $15 \mathrm{~min}$ and inoculated with the isolated strains. After 24,48 and 72 hour incubation enzyme activity was carried out.

\subsubsection{Strain No-1}

Strain no.1 was found to produce maximum amylase at 48 hour. Therefore this strain was further studied for optimization of different growth and enzyme production parameters which are substrate concentration, organic and inorganic nitrogen concentration, different $\mathrm{pH}$, inoculums size, aeration and temperature.

\subsubsection{Enzyme Assay (Amylase Assay)}

Enzyme activity was determined by dinitro salicylic acid method (DNS) using starch as a substrate. The reaction mixture contained $10 \mathrm{mg}$ starch $100 \mu \mathrm{g}$ or $0.1 \mathrm{ml}$ crude protein (broth) in 50mili molar sodium phosphate buffer $\mathrm{pH} 7.0$. The reaction mixture was incubated at $37^{\circ} \mathrm{C}$ for 30 minutes and the reaction was terminated by adding $3 \mathrm{ml}$ DNS solution. After stopping the reaction the tubes were placed in a boiling water bath for 5 minutes and then cooled and absorbance was taken at 540nm in a UV double beam spectrophotometer .The amount of glucose produced was calculated by referring to the standard curve using glucose as the reducing sugar in 1minute under assay conditions.

III. Results And Discussion

Table 4.Effect of Different Concentrations of Starch on Amylase Production

\begin{tabular}{|c|c|c|}
\hline Concentration of $\operatorname{starch}(\%)$ & Absorbance at 540nm & Glucose concentration $(\boldsymbol{\mu g} / \mathrm{ml} / \mathrm{min})$ \\
\hline 0.75 & 0.792 & 10 \\
\hline 1.0 & 0.910 & 12.83 \\
\hline 1.25 & 0.104 & 9.12 \\
\hline
\end{tabular}




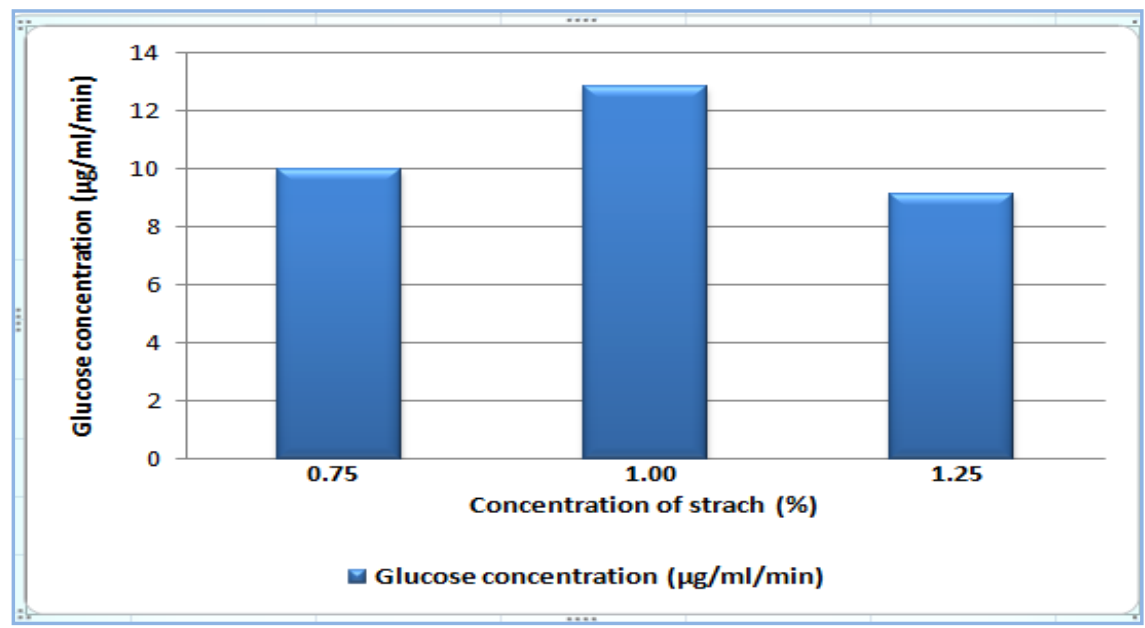

Figure 2. Effect of Different Concentrations of Starch on Amylase Production

Table 5.Effect of Temperature onAmylase Production.

\begin{tabular}{|c|c|c|c|c|}
\hline $\begin{array}{c}\text { Temperature } \\
{ }^{\circ} \mathrm{C}\end{array}$ & $\begin{array}{c}\text { Absorbance } \\
\text { at540nm }(24 \mathrm{hrs})\end{array}$ & Glucose conc. $(\mu \mathrm{g} / \mathrm{ml} / \mathrm{min})$ & $\begin{array}{c}\text { Absorbance } \\
\text { at540nm (48hrs) }\end{array}$ & $\begin{array}{c}\text { Glucose conc. } \\
(\mu \mathrm{g} / \mathrm{ml} / \mathrm{min})\end{array}$ \\
\hline 25 & 0.786 & 10 & 0.769 & 8.83 \\
\hline 28 & 0.100 & 1.16 & 0.109 & 1.33 \\
\hline 32 & 0.104 & 1.23 & 0.102 & 1.20 \\
\hline 37 & 0.773 & 9.88 & 0.765 & 9.33 \\
\hline 40 & 0.737 & 9.43 & 0.729 & 8.92 \\
\hline
\end{tabular}

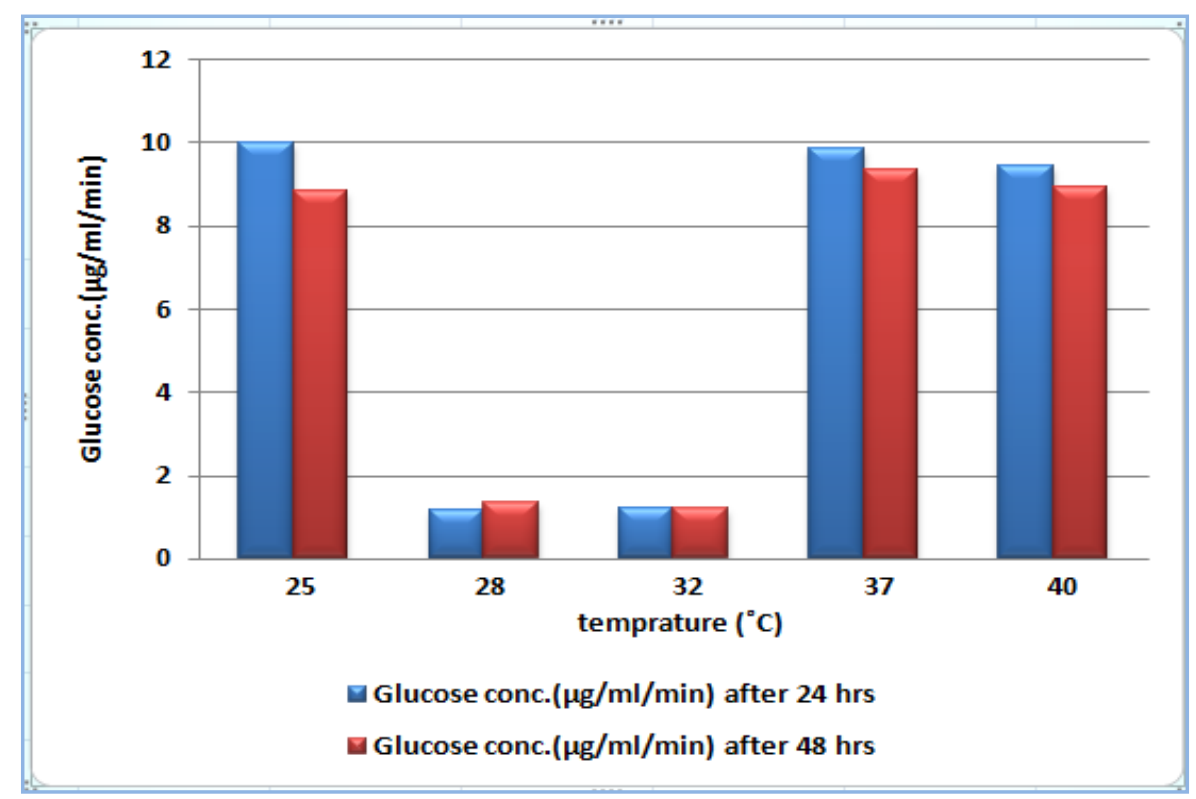

Figure 3. Effect of Temperature on Amylase Production

Table 6.Effect of Aeration onAmylase Production.

\begin{tabular}{|c|c|c|c|c|}
\hline Rpm & $\begin{array}{c}\text { Absorbance at 540 } \\
\text { nm }(24 \mathrm{hrs})\end{array}$ & $\begin{array}{c}\text { Conc. of glucose } \\
(\mu \mathrm{g} / \mathrm{ml} / \mathrm{min})\end{array}$ & $\begin{array}{c}\text { Absorbance at 540 } \\
\text { nm }(48 \mathrm{hrs})\end{array}$ & $\begin{array}{c}\text { Conc. of glucose } \\
(\mu \mathrm{g} / \mathrm{ml} / \mathrm{min})\end{array}$ \\
\hline 100 & 0.797 & 10.13 & 0.995 & 12.83 \\
\hline 120 & 0.972 & 12.46 & 1.025 & 13.16 \\
\hline 140 & 0.925 & 11.86 & 0.944 & 12.00 \\
\hline
\end{tabular}




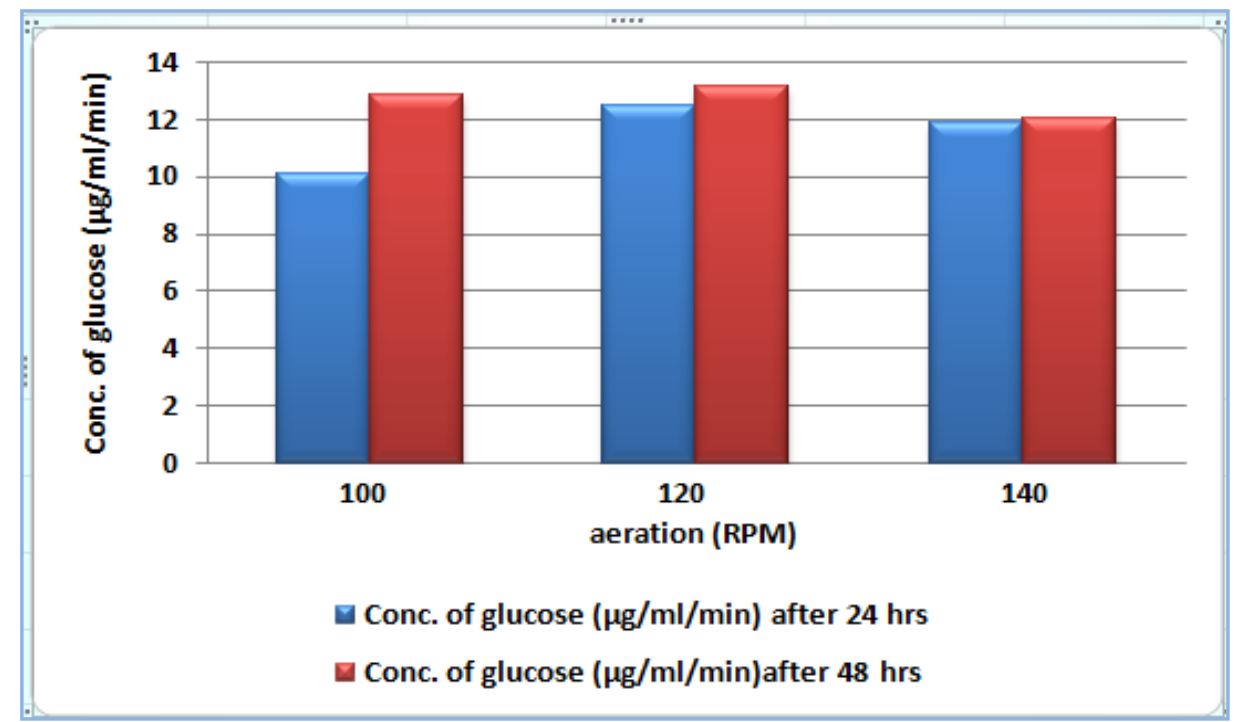

Figure 4.Effect of Aeration on Amylase Production.

Table 7.Effect ofInoculums Size on Amylase Production

\begin{tabular}{|c|c|c|c|c|}
\hline $\begin{array}{c}\text { Inoculum Size } \\
\%\end{array}$ & $\begin{array}{c}\text { Absorbance at 540 } \\
\text { nm }(24 \mathrm{hrs})\end{array}$ & $\begin{array}{c}\text { Conc. of glucose } \\
(\mu \mathrm{g} / \mathrm{ml})\end{array}$ & $\begin{array}{c}\text { Absorbance at 540 } \mathrm{nm} \\
(\mathbf{4 8} \mathrm{hrs})\end{array}$ & $\begin{array}{c}\text { Conc. of glucose } \\
(\boldsymbol{\mu g} / \mathbf{m l})\end{array}$ \\
\hline 0.50 & $\mathbf{0 . 8 8 2}$ & 11.33 & $\mathbf{0 . 8 8 8}$ & 11.33 \\
\hline 1.0 & 0.774 & 9.83 & $\mathbf{0 . 8 5 8}$ & 1083 \\
\hline 1.5 & 0.886 & 11.33 & 0.896 & 12.33 \\
\hline 2.0 & 0.656 & 8.16 & 0.799 & 10.16 \\
\hline
\end{tabular}

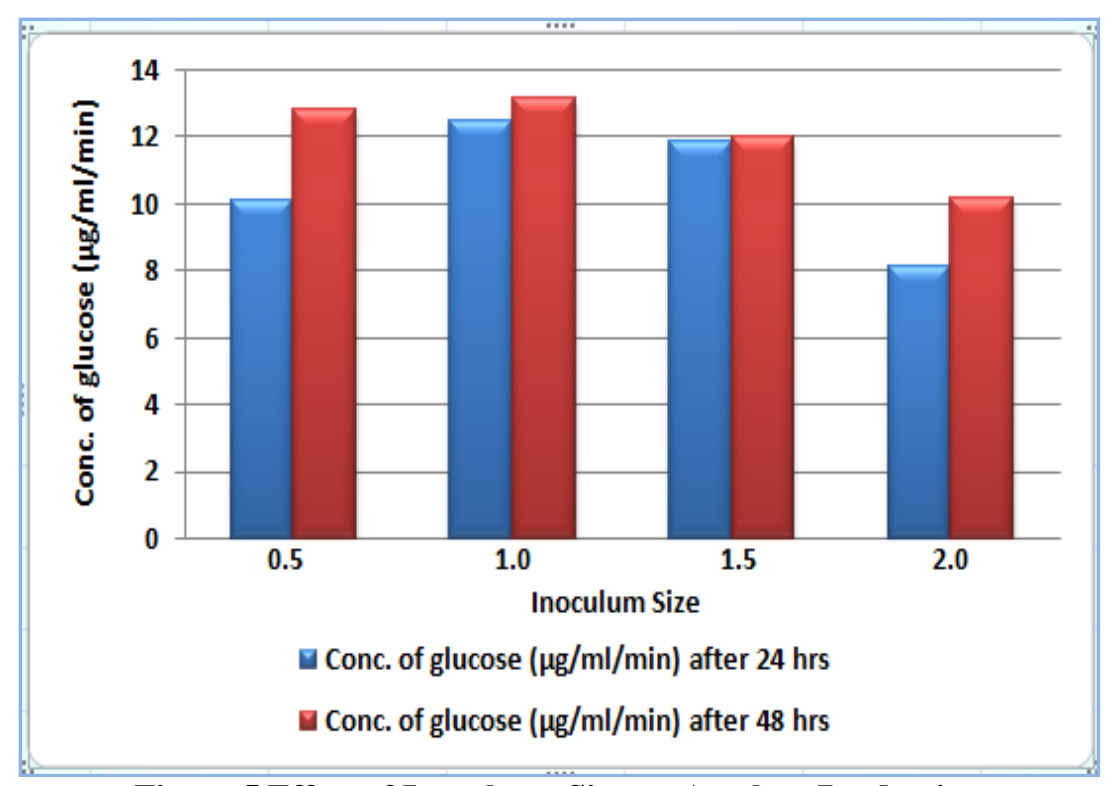

Figure 5.Effect of Inoculums Size on Amylase Production

Table 8.Effect ofpH on Amylase Production

\begin{tabular}{|c|c|c|c|c|c|c|}
\hline pH & $\begin{array}{c}\text { Absorbance } \\
\text { at } 540 \text { nm } 24 \\
\text { hrs }\end{array}$ & $\begin{array}{c}\text { Conc. of } \\
\text { glucose } \\
\mu \mathrm{g} / \mathrm{ml} / \mathrm{min}\end{array}$ & $\begin{array}{l}\text { Absorbance at } \\
540 \mathrm{~nm} 48 \mathrm{hrs}\end{array}$ & $\begin{array}{c}\text { Conc. of } \\
\text { glucose } \\
\mu \mathrm{g} / \mathrm{ml} / \mathrm{min}\end{array}$ & $\begin{array}{l}\text { Absorbance at } \\
540 \mathrm{~nm} 72 \mathrm{hrs}\end{array}$ & $\begin{array}{c}\text { Conc. of } \\
\text { glucose } \\
\mu \mathrm{g} / \mathrm{ml} / \mathrm{min}\end{array}$ \\
\hline 6.5 & 0.201 & 2.5 & 0.217 & 2.83 & 0.145 & 1.66 \\
\hline 7.0 & 0.222 & 2.83 & 0.215 & 2.76 & 0.186 & 2.33 \\
\hline 7.5 & 0.197 & 2.18 & 0.165 & 1.93 & 0.181 & 2.16 \\
\hline 8.0 & 0.147 & 1.02 & 0.151 & 1.16 & 0.169 & 1.18 \\
\hline
\end{tabular}




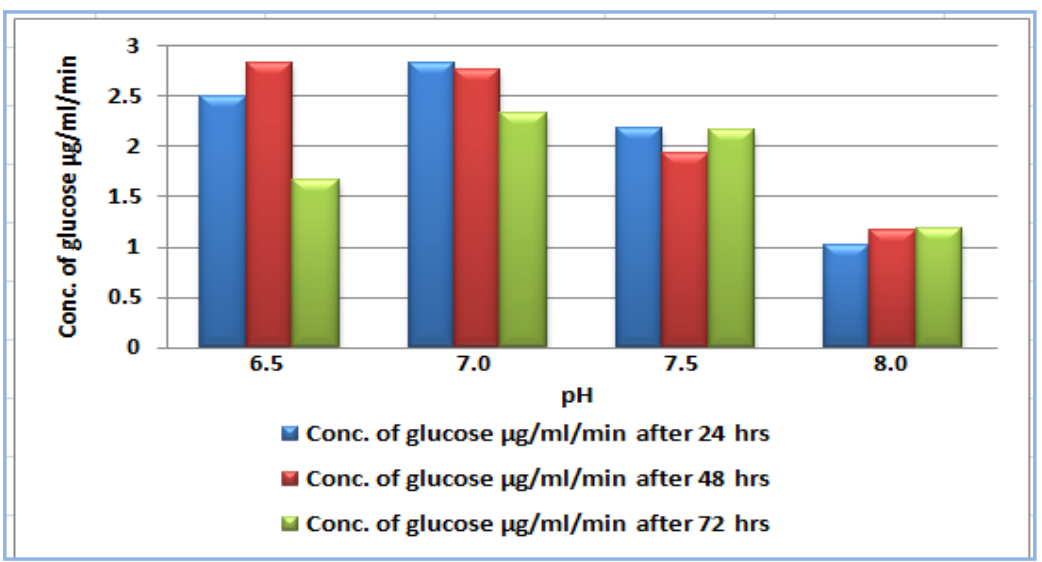

Figure 6.Effect of $\mathrm{pH}$ on Amylase Production

The occurrence of amyloytic organisms from the soil agrees with earlier reports. Reportedthat the soil is known to be a store house of amylase producing bacteria and fungi (Rehana and Nand., 1989, Adebiyi et al., 1998).

The amylase producing bacterial colonies were grown on nutrient agar plate containing $1 \%$ starch which after growth of 24 hrswereflooded with grams iodine showed a sharp zone of hydrolysis of starch with the blue black background (A.K.Ponet al., 1999). A number of reports are available in the literature regarding the influence of various environmental conditions of growth parameters like effect of $\mathrm{pH}$, optimum temperature, inoculation incubation period, carbon source \& their concentration, nitrogen sources and their concentrations etc. on the production of amylase.

Increase in the incubation period resulted decreases in the amylase production. It may be due to the fact that after maximum production of the amylase the production of other enzymes as well as by products and depletion of the nutrients. These by-products inhibited the growth of bacteria and enzyme formation. The starch concentration is a factor of amylase production. In this experiments we found that $1 \%$ starch concentration is appropriate for amylase production (Figure.2).

The temperature of incubation at $37^{\circ} \mathrm{C}$ was found most suitable for amylase production among the various incubation temperatures studied(Figure.3).

Aeration or supply of oxygen is another important parameter of growth and production which can be provided in shake flask studies either by reduction in volume of medium or by increasing the shaker speed or by both. In our studies we tried to provide oxygen to the culture by increasing the shaker speed at different RPM. It was observed that maximum amylase was produced at 120 RPM (Figure.4).The size of inoculum is another factor of amylase production. In this experiments for the detection of an appropriate inoculum volume we found that $1 \% \mathrm{v} / \mathrm{v}$ inoculum is sufficient for amylase production (Figure.5).

The enzyme is very sensitive to $\mathrm{pH}$ therefore a selection of optimum $\mathrm{pH}$ is very essential. Amylase production was therefore studied at $\mathrm{pH}$ 6.0, 6.5, 7.0, 7.5 and 8. Highest amylase production was noted at $\mathrm{pH} 7.0$. It was observed that both organic \& inorganic nitrogen were essential for growth of bacillus as well as the production of amylase (Figure.6).

\section{References}

[1]. A.K. Pon, I., M.O Bonkriy and A.M, A.Desemomo, 1999a. A rapid plate culture method for screening of amylase producing microorganism. Biotechnol.tech. 13; 411-413.

[2]. Allan, S., B.F. Henrik and B. Torbenvedel, 1996. A method of designing alpha mutants, with predetermined properties alpha amylase varients and detergents containing the variants. Process Birchem.,31: 110-210.

[3]. Adebiyi, C. A. B. and J. A. A Kinyanju, 1998. Thermophilic amylase produces from the soil Nig. Journal. Science. Technol, 11; 1338.

[4]. Busch JE, Stutzenberger FJ. Amylolytic activity of Thermomonosporafusca. World Journal of Microbiology and Biotechnology, 1997; 13:637-642.

[5]. Calik, P. and T.H. Ozdamar, 2001. Carbon sources affect metabolic capacities of Bacillus species for the production of industrial enzymes. Biochem. Eng. J., 8: 61-81.

[6]. Guzman- Maldonado, H., Paredes, O. Amyloytic enzymes and products derived from starch. Criticsrevs. food sci. nutria. 1995 33: 373-403.

[7]. Ivanona, V.N., E.P. Dobreva and E.I. Emanuilova, 1993. Purification and charaterization of a thermostable alpha-amylase from Bacilluslicheniformis. J. Biotechnol., 28: 277-89.

[8]. Kim, T.U., G.B. Gum., J.Y. Jeong and S.C. Young, 1995. Purification and characterization of a maltotetraose forming alkaline alpha amylase from an alkalophilicBacillus strain, GM 8901. Appl. Environ.Microbiol.,61:3105-12.

[9]. Mamo, G. and A. Gessesse, 1999. Effect of cultivation conditions on growth and amylase production by a thermophilicBacillus sp.Lett. App. Mitrobiol, 29: 61-5.

[10]. Rehna, F.B, and K.Nand, 1989 perimenalery studies on the production of thermostable amylase by masochistic stain of bacillus licheniformis. Chem. Microbial, technol. Leberism. 12; 8-13.

[11]. Vidyalakshmi P, Paranthaman R, Indhumathi J. Amylase Production on SubmergedFermentation by Bacillus spp. World Journal of Chemistry, 2009; 4 (1): 89-91. 